\title{
Dzieje i kultura cystersów w Polsce 1, pod red. Marcina Starzyńskiego, Dariusza Tabora CR, Societas Vistulana, Kraków 2016, ss. 280 (Cistercium Mater Nostra. Studia et Documenta, 3)
}

Zakon „szarych mnichów" powstał na bazie reformy, której zwolennicy postulowali prostotę, surowość oraz przede wszystkim powrót do pierwotnej reguły św. Benedykta. Tak nakreślone aksjomaty cystersi starali się wdrażać we wszystkie dziedziny klasztornego życia ${ }^{1}$. Dziedziny te zostały poddane wszechstronnym badaniom, które obejmowały kwestie związane z historycznymi aspektami przeprowadzonych fundacji składem osobowym, działalnością gospodarczą, jak i lokacyjną "szarych mnichów", ale także architekturą, sztuką oraz muzyką. Nie pominięto zagadnień duchowości, piśmiennictwa czy działalności misyjnej. Wynikiem podjętych na szeroką skalę badań, jest powstała imponująca pod względem ilości i różnorodności literatura zarówno polska, jak i zagraniczna ${ }^{2}$.

1. A. M. Wyrwa, Powstanie cystersów i jego rozwój na ziemiach polskich w średniowieczu, w: Monasticon Cisterciense Poloniae, t. 1: Dzieje i kultura męskich klasztorów cysterskich na ziemiach polskich i dawnej Rzeczpospolitej od średniowiecza do czasów współczesnych, red. A. M. Wyrwa, J. Strzelczyk, K. Kaczmarek, J. Dobosz, Poznań 1999, s. 28-33.

2. M.in. T. Manteuffel, Papiestwo i cystersi: ze szczególnym uwzględnieniem ich roli w Polsce na przełomie XII i XIII w., Warszawa 1955; Historia i kultura cystersów w dawnej Polsce $i$ ich europejskie związki, red. J. Strzelczyk, Poznań 1987 (Historia, 135); Cystersi w kulturze średniowiecznej Europy, red. J. Strzelczyk, Poznań 1992; Monasticon Cisterciense Poloniae, t. 2: Katalog męskich klasztorów na ziemiach 
Przybywające stale nowe publikacje świadczą o tym, że pomimo znaczącej wiedzy i studiów na temat zakonu cystersów nadal pewne obszary wymagają pogłębionych badan i analiz. W kręgach badaczy zajmujących się powyższą tematyką pojawiają się godne uwagi inicjatywy angażujące uczonych różnych dyscyplin naukowych do podjęcia dyskusji nad osobliwością zakonu cysterskiego. Przykładem tego rodzaju inicjatyw są seminaria dotyczące sztuki i kultury duchowej cystersów organizowane przez katedrę Historii Sztuki Starożytnej i Średniowiecznej Uniwersytetu Papieskiego Jana Pawła II w Krakowie. Recenzowana publikacja stanowi pokłosie ostatniego seminarium w ramach powyższego cyklu, które miało miejsce w 2014 roku. Pojawia się zatem pytanie, co owa praca wniosła do tematyki badań nad klasztorami cystersów na ziemiach polskich.

Na wstępie należy zaznaczyć, że redaktorzy stanęli przed trudnym zadaniem, charakterystycznym dla każdej pracy zbiorowej, jakim jest wyselekcjonowanie i uporządkowanie materiału. Struktura książki jest spójna i logiczna, co niewątpliwie wpływa na wartość publikacji. Praca składa się z czterech bloków tematycznych, dotyczących: architektury i krajobrazu, sztuki i liturgii, piśmiennictwa oraz historii i dziedzictwa. Zaprezentowane badania obejmują swym zasięgiem działalność cystersów na ziemiach polskich oraz w Europie. Pod względem chronologicznym praca ma charakter przekrojowy, gdyż znajdziemy w niej artykuły z różnych epok, poczynając od średniowiecza po współczesność. Umożliwia to prześledzenie żywotności i trwałości pewnych motywów i symboli w kulturze cysterskiej.

Uczestnikom seminarium przyświecał cel poznania i ukazania czytelnikowi charyzmatu cysterskiego, który został zdefiniowany jako grupa wartości posiadanych i przekazywanych, ale także kształtowanych przez wspólnoty mnisze. Wartości te budują tożsamość wspólnoty oraz wpływają na interakcje ze społeczeństwem. Jest to założenie dość ogólne, umożliwiające dużą

polskich i dawnej Rzeczpospolitej, red. A. M. Wyrwa, J. Strzelczyk, K. Kaczmarek, Poznań 1999; Cystersi w społeczeństwie Europy Środkowej. Materiały z konferencji naukowej odbytej w klasztorze oo. Cystersów w Krakowie Mogile z okazji goo rocznicy powstania Zakonu Ojców Cystersów. Poznań-Kraków-Mogiła 5-1o października, red. A. M. Wyrwa, J. Dobosz, Poznań 2000; I. Kołodziejczyk, Duchowość cysterska, Kraków 2002; K. Morajko OCist, Charyzmat zakonu cystersów. Studium historyczno-prawne, Kraków 2006; P. Droździk, M. Wcześny, Cystersi w Polsce, Nowy Sącz 2009; I. Eberl, Cystersi: historia zakonu europejskiego, przeł. P. Włodyga, Kraków 2011; P. Droździk, M. Wcześny, Cystersi w Wąchocku, Nowy Sącz 2013; Cystersi w Polsce: podstawowe dokumenty, red. P. Chojnacki OCist, W. Polek OCist, K. Jankosz OCist, Kraków 2014. 
swobodę interpretacji tematyki seminarium, a jednocześnie kompleksowe, gdyż daje sposobność do prześledzenia, w jaki sposób cystersi stosowali się do swoich zasad i w jakich dziedzinach życia się one przejawiały.

Pierwszy blok tematyczny - Architektura i krajobraz - rozpoczyna artykuł Ewy Łużynieckiej. Dotyczy on studiów nad architekturą francuskich klasztorów cysterskich w Obazine i Grosbot. Owe studia Łużyniecka podjęła wraz z zespołem badawczym Wydziału Architektury Politechniki Wrocławskiej, którego była kierownikiem. Czytelnikowi została nakreślona geneza obu wspólnot oraz czas włączenia ich do zakonu cysterskiego. Następnie autorka zaprezentowała wyniki badań dotyczące zarówno przeobrażeń budynków, jak i kościołów klasztornych. Szczegółowy i wnikliwy opis dokonanych zmian architektonicznych należałoby wzbogacić o wnioski odnoszące się do cysterskich charyzmatów, a dokładnie, czy ujawniły się one w badaniach autorki i jeżeli tak, to w jaki sposób. Ponadto tytuł owej publikacji sugeruje nam, że zawarte w niej artykuły będą dotyczyć dziejów i kultury cystersów w Polsce. W związku z tym pojawia się pytanie, czy istnieją kontakty pomiędzy cystersami z Obazine i Grosbot a cystersami z ziem polskich. Odpowiedź wydaje się być jednak przecząca, gdyż wpływ na rozwój tych dwóch francuskich klasztorów, jak i ich architektury miał zapewne fakt, że dopiero po pewnym czasie zostały one inkorporowane do zakonu cystersów. Natomiast klasztory na ziemiach polskich były filiami opactwa Morimond w bezpośredni (tzw. grupa małopolska) lub pośredni sposób (Wielkopolska, Śląsk)³, i to właśnie stamtąd czerpano główne wzorce. Tekst może jednak stanowić punkt wyjścia do badań nad podobieństwami i różnicami pomiędzy cystersami na ziemiach polskich a cystersami z innych terenów europejskich.

W kolejnym artykule zaprezentowane zostały wyniki badań archeologiczno-architektonicznych strefy domu opackiego w Mogile, autorstwa Anny Bołęś-Błasik oraz Dariusza Niemca, którzy utworzyli dwuosobowy zespół badawczy. Wykazali liczne przebudowania w części klasztoru związanej z siedzibą opacką i dokonali weryfikacji dotychczasowych ustaleń. Dzięki przeprowadzonym badaniom odkryto piec hypokaustyczny z pierwszej połowy XV wieku, XVIII-wieczny kanał ściekowy oraz wczesnorenesansową klatkę schodową. Autorzy wykazali się dużą kompetencją oraz szczegółowością

3. Z. Świechowski, Architektura cystersów w Polsce, Czechach i na Węgrzech, w: Cystersi w społeczeństwie Europy Środkowej..., dz. cyt., s. 55, 59, 63; A. Gajewski, Inne spojrzenie na architekturę cysterska. Część 1: Ideał architektury cysterskiej jako zwierciadło czasu, "Cistercium Mater Nostra" 4 (2010), s. 21-32. 
analiz, lecz jak w powyższym przypadku odczuwalny jest brak odwołania się do cysterskich postulatów architektonicznych ${ }^{4}$.

Ostatnim artykułem w tej części jest tekst Bogusława Krasnowolskiego odnoszący się do działalności osadniczej cystersów z Koprzywnicy, stanowiący jednocześnie, jak zaznacza autor na wstępie, kontynuację wcześniejszych studiów nad planami urbanistycznymi miast (m.in. Kraków, Zawichost czy Sącz). W związku z tym Krasnowolski poddał analizie plany urbanistyczne Jasła i Koprzywnicy, wykazując pomiędzy owymi miejscowościami znaczne podobieństwa, które zaobserwował także w innych miastach małopolskich związanych ze wspólnotami cysterskimi. Owe prawidłowości dotyczyły regularnego planu miast oraz wsi, według którego cystersi wyznaczali określoną przestrzeń dla sfery sacrum, budynków mieszkalnych oraz użytku publicznego, a także tereny na działalność rolniczą. Co więcej, planowanie przestrzeni przez mnichów z Koprzywnicy miało charakteryzować się pragmatyzmem oraz regularnością, poprzez które nawiązywano do idei średniowiecznych uniwersaliów.

Kolejna część została poświęcona sztuce i liturgii, gdzie w czterech artykułach badacze zaprezentowali wyniki swoich badań dotyczące ikonografii i malarstwa cysterskiego. Dariusz Tabor CR wziął na warsztat graduał lubiąski oraz cysterski antyfonarz z Lubiąża, gdzie znajdują się miniatury przedstawiające mistrza w otoczeniu uczniów. Badacz zaproponował nowy sposób interpretacji owych przedstawień, postulując, aby w analizach cysterskich miniatur kierować się Lectio divina oraz consederatio, które są właściwe dla duchowości cysterskiej. Wedle tej optyki opat-mistrz jawi się jako osoba przygotowująca mnichów do modlitwy, a następnie kontemplacji, które prowadzą do spotkania i tym samym doświadczenia Boga, będąc jednocześnie wstępem do doskonalenia osobistego poszczególnych członków wspólnoty.

W następnym artykule Mateusza Kawa OCist ukazuje charakterystyczne przedstawienia ikonograficzne św. Bernarda z Clavirvaux, które zostały pogrupowane w cztery podstawowe typy (portret, św. Bernard z Matką Bożą, z Chrystusem ukrzyżowanym, sceny z życia opata), w ramach których badacz konstruuje swoją narrację. Wyróżnionym wariantom przedstawień towarzyszy wnikliwa analiza, dzięki której poznajemy źródła ujęć świętego. Ponadto autor podaje także najstarsze przykłady tego rodzaju ikonografii u cystersów na ziemiach polskich.

4. A. Gajewski, Inne spojrzenie na architekturę cysterska..., dz. cyt., s. 22-24. 
Malowidła ścienne Stanisława Samostrzelnika i rola grafiki w ich powstawaniu była przedmiotem badań Beaty Frey-Stecowej. Autorka na wstępie zarysowała postać Stanisława Samostrzelnika, a także okoliczności odkrycia malowideł. Głównym jednak jej zadaniem było wykazanie wzorów graficznych, którymi posłużył się cysterski mnich. Autorka nie wychodzi poza strefę dotychczasowych ustaleń, dodaje jednak nowe argumenty poperające tezę Andrzeja Mieczysława Olszewskiego o szczególnej roli dorobku niemieckiego artysty Albrechta Dürera w twórczości Samostrzelnika.

Malarstwo religijne Janusza Matuszewskiego stanowiło przedmiot analiz Adama Organistego. Matuszewski jest współczesnym artystą, który w 2008 roku przekazał mnichom cysterskim z krakowskiej Mogiły swoje dzieło przedstawiające św. Bernarda z Clairvaux. Bezpośrednie wzorce do tego obrazu artysta czerpał od Domenica Theocopulosa (El Greca). Autor niniejszego szkicu ukazuje nam źródła inspiracji Matuszewskiego, ale także przedstawia twórczość owego artysty oraz etapy jej formowania, co pozwala na podjęcie próby interpretacji jego dzieł. Artysta w swych pracach wykorzystał typowe motywy przedstawień Opata z Clairvaux, był pod szczególnym wpływem baroku, ale także samej duchowości i formacji cysterskiej.

Rozdział poświęcony piśmiennictwu otwiera artykuł Marka Piotra Chojnackiego OCist, w którym to autor odwołał się do metafory gołębicy w pismach św. Bernarda z Clairvaux. W tym celu ukazał źródła, z których została zaczerpnięta tradycja interpretacyjna. Tym samym przedstawił ważne elementy duchowości i teologii cysterskiej, które chciał w swych pismach i naukach przekazać św. Bernard.

Artykuł Marcina Starzyńskiego stanowi interesujące studium, dzięki któremu poznajemy sposób pracy i podejście do dziejów wspólnoty pierwszego mogilskiego kronikarza. Należy zaznaczyć, że kroniki klasztorne są niezwykle ciekawym źródłem, które nie tylko umożliwia poznanie dziejów wspólnoty, ale także osobę piszącego, m.in. jego podejście do dat, wydarzeń i otaczającej rzeczywistości. Starzyński zwrócił uwagę na te ważne aspekty, ukazując sposób pozyskiwania wiedzy, podejście do historii wspólnoty i dziejów ogólnych, dokładność i wiarygodność pisarza, a także nakreślił jego osobowość. Pojawia się pytanie, w jaki sposób cysterski mnich wypowiadał się o swojej wspólnocie i czy są bezpośrednie odniesienia na kartach kroniki do duchowości, czy bardziej ogólnie - do charyzmatu cysterskiego.

Dwa ostatnie artykuły tej części poświęcone zostały kronice koprzywnickiej, pierwszy to studium źródłoznawcze Zofii Kozłowskiej, które 
zostało wprowadzone do obiegu naukowego i przygotowane do druku przez Starzyńskiego. Drugi artykuł to szkic Macieja Zdanka ukazujący aktualny stan wiedzy na temat kroniki oraz perspektywy badań nad nią. Autor zapowiedział, że źródło „w najbliższej przyszłości stanie się przedmiotem podstawowych studiów źródłoznawczych oraz edycji krytycznej z polskim tłumaczeniem" (s. 188).

Ostatni rozdział - Historia $i$ dziedzictwo - zawiera jeden tekst autorstwa Tomasza Graffa, poświęcony patronatowi cystersów mogilskich nad kościołem pw. Wszystkich Świętych w Wadowicach. Historyk przedstawił aktualny stan badań oraz własną opinię na temat cysterskiego patronatu, który wedle badacza, wbrew ostatnim ustaleniom, nie wywierał szczególnego znaczenia na życie religijne wadowickiej społeczności.

Konkludując, niniejsza publikacja uaktualnia stan badań nad zakonem cystersów, co pozwala na głębsze poznanie zarówno wspólnot, jak i ich duchowości, umożliwia także prześledzenie, w jaki sposób cysterskie klasztory rozwijały się na przełomie wieków. Nawiązanie do wzorów europejskich prowadzi do zrozumienia występowania pewnych motywów czy symboliki u cysterskich wspólnot na ziemiach polskich. Zamieszczenie podsumowania mogłoby stanowić dopełnienie owej pracy, gdyż seminarium na pewno przyniosło wiele ciekawych wniosków, dziś czytelnikowi niedostępnych. Recenzowane studia oczywiście nie wyczerpują tematyki klasztorów cysterskich, jednakże wymienione szkice wyznaczaja program badawczy na przyszłość, postulując nowoczesne i interdyscyplinarne podejście do kwestii dziejów i kultury tego zakonu. 